April 2007

\title{
In the Footsteps of Raphael Lemkin
}

Michael J. Bazyler

Follow this and additional works at: https://digitalcommons.usf.edu/gsp

\section{Recommended Citation}

Bazyler, Michael J. (2007) "In the Footsteps of Raphael Lemkin," Genocide Studies and Prevention: An International Journal: Vol. 2: Iss. 1: Article 7.

Available at: https://digitalcommons.usf.edu/gsp/vol2/iss1/7

This Articles is brought to you for free and open access by the Open Access Journals at Digital Commons @ University of South Florida. It has been accepted for inclusion in Genocide Studies and Prevention: An International Journal by an authorized editor of Digital Commons @ University of South Florida. For more information, please contact digitalcommons@usf.edu. 


\title{
In the Footsteps of Raphael Lemkin
}

\author{
Michael J. Bazyler \\ Professor of Law and "1939" Club Law Scholar in Holocaust and \\ Human Rights Studies, Whittier Law School; Distinguished Visiting \\ Professor of Law, Pepperdine University School of Law (2007)
}

When Raphael Lemkin invented the word "genocide" in 1944, he explained that this is a "new word, coined by the author to denote an old practice in its modern development." 1 As Lemkin wrote these words, the paradigmatic genocide, the Holocaust, was raging in Europe.

Since Lemkin was a lawyer, he put great weight on both national and international legal rules as one of the best tools to prevent and eventually eradicate this "old practice." His response was to propose an international crime for which individuals committing such acts against a group of people-whom he labeled "a collectivity" - could be punished, irrespective of national boundaries. In effect, Lemkin was proposing the now-accepted rule of universal jurisdiction, whereby individuals committing certain heinous crimes are considered hostis humani generis-enemies of all humankind-and can be prosecuted by any national or international court, regardless of where the crime was committed. ${ }^{2}$

It is the legalistic background of the inventor and the purpose for which the term was invented-to make certain group behavior an international crime recognized by the community of nations as illegal through a multilateral treaty-that put the term "genocide" solidly within a legal framework.

The culmination of Lemkin's work during his lifetime was the Convention on the Prevention and Punishment of the Crime of Genocide (UNCG), adopted by the UN General Assembly in 1948 and entering into force in 1951. More than 130 states today are parties to the UNCG, in whose article 1 they solemnly "undertake to prevent and punish" genocide. ${ }^{3}$ How states are to do so is left unstated in the treaty.

Though Lemkin died impoverished and in relative obscurity in 1959, his word has achieved a recognition beyond his dreams. "Genocide" has now become synonymous with extreme evil and, as noted by William Schabas, the "crime of crimes."4 A Google search today yields more than 26 million entries for the term.

Unfortunately, one of the major reasons for its widespread popularity is the failure of the UNCG to prevent repeated occurrences of this particular extreme evil. While the term "genocide" should by now be relegated to descriptions of historical events, most recently the Holocaust, it is instead still being used by those who followed Lemkin to describe current events. As explained by Gregory Stanton,

When the Genocide Convention was passed by the United Nations in 1948, the world said, "Never again." But the history of the twentieth century instead proved that "never again" became "again and again." The promise the United Nations made was broken, as again and again, genocides and other forms of mass murder killed 170 million people, more than all the international wars of the twentieth century combined. ${ }^{5}$

As I write this commentary, a genocide is raging in the Darfur region of Sudan while the international community, in "Keystone Kops" fashion, haplessly tries to figure out how to respond to the events. Despite massive demonstrations, 
letter-writing campaigns to politicians, public appeals, and extensive coverage by the media, the genocide in Darfur continues unabated. As Jerry Fowler recently explained in a more elegant manner,

Darfur adds another sad chapter of irony in the convention's history, given the dramatic incongruity between the sense of urgency that one might expect a plausible case of ongoing genocide to engender and the relatively lackadaisical international political response that has in fact unfolded. ${ }^{6}$

The failure of the international community to stop the Rwandan genocide of 1994, during which approximately one million victims were murdered over a period of 100 days, provides another sad and sorry example of the "again and again" phenomenon.

As we approach the half-century mark of Lemkin's death, it is a great blot on both international law and international diplomacy that we have failed miserably to make his dream into reality and relegate genocide to the trash bin of history.

Not that we haven't tried. Numerous proposals, some put into practice, have been offered over the last fifty years to make the work of genocide prevention more effective. The topic has also been the subject of numerous books, articles, policy papers, and speeches. 7

In the 1970s, Israel Charny and Chanan Rapaport devised the Genocide Early Warning System (GEWS), an analytic process by which to recognize preludes to genocide so that effective action can be taken before events on the ground escalate into full-blown genocide. GEWS is based on the fact that genocides, including the Holocaust, are never spontaneous events; rather, they occur incrementally, in predictable steps. ${ }^{8}$

In the 1990s, Gregory Stanton addressed the same issue and gave us an important tool by likewise identifying the signposts on the road to genocide. Stanton explains that "genocide is a process that develops in eight stages that are predictable but not inexorable. At each stage, preventive measures can stop it. The later stages must be preceded by the earlier stages, though earlier stages continue to operate throughout the process." 9

At the policy level, UN Secretary-General Kofi Annan took a stab at the task in 2004 by creating the position of Special Adviser on the Prevention of Genocide and appointing Juan Méndez, law professor, human rights advocate, and former political prisoner from Argentina, to the post. Events in Darfur demonstrate, at least to date, that the addition of such a special adviser for genocide prevention at the UN has had little effect in the real world. In 1997, the Clinton administration in the United States had created a new post in the US State Department, the US Ambassador at Large for War Crimes Issues, with a similar mandate to focus on genocide and other large-scale violations of international criminal law. The creation of this post has likewise had, at most, a negligible effect on the task of genocide prevention and the current holder of the position, John Clint Williamson, seems to play a minor role in the State Department. Prior to Williamson's appointment in April 2006, the post was vacant for six months.

David Scheffer, the first ambassador for war crimes issues and currently a law professor at Northwestern University, now offers another proposal to make genocide prevention more effective.

Scheffer correctly points out that the legal definition of genocide, as found in the UNCG, has acted to constrain genocide prevention, since it offers both the United Nations and individual nations a ready-made legal excuse not to take action. It allows them to claim that the acts being committed, while horrible, have not yet risen 
to the level of genocide as set out in the legal definition, with its hard-to-meet requirement of specific intent. As Scheffer puts it, "The prospect of the term 'genocide' arising in policy making too often puts an intimidating brake on effective responses." 10 Thus, while the genocide in Rwanda was ongoing, the Clinton administration shied away from calling the events a "genocide," since it was believed that the use of the "G-word" required action.

Scheffer proposes that the "political use of the term should be separated from its legal definition as a crime of individual responsibility. Governments and international organizations should be allowed to apply the term genocide more readily within a political context." In Scheffer's terms, they should be "liberated so as to publicly describe precursors of genocide and react rapidly to prevent or to stop mass killings or other seeming acts of genocide." ${ }^{11}$ How to do this? Scheffer suggests that a new phrase be employed to describe the coming storm of genocide: "precursors of genocide," which he argues is "useful, pragmatic and sufficiently diplomatic to employ without necessarily triggering some of the intimidating consequences of charges of genocide." ${ }^{2}$ The phrase "precursors of genocide" also has the advantage of using the G-word to bring public and media attention to the events-as perhaps no other word can do-while at the same time qualifying it to imply that we have not yet reached the worst of the situation but may do so if rapid action is not taken. It also allows the politicians and diplomats to do their job without the lawyers' coming in and mucking up the situation by pointing out that specific intent and other legal elements of the crime cannot be shown.

Scheffer then goes one step further by proposing the use of another new term"atrocity crimes"-in both political and legal contexts to cover those acts that warrant action. Atrocity crimes, in Scheffer's lexicon, constitute not only genocide but those crimes that are precursors to genocide and to which, in any case, either an international or a national response is required: namely, crimes against humanity and serious war crimes. In effect, Scheffer concludes that the term "genocide" carries too much baggage and thus weighs down decision makers (whether at the United Nations or in individual governments), preventing them from responding to events that occur in his so-termed "atrocity zone."

Scheffer's proposal is modest, and he concedes that "what is proposed...supplements the many [other] proposals on genocide prevention." ${ }^{3}$ Following in the footsteps of Lemkin, Scheffer focuses, as he puts it, "on the terminology employed." ${ }^{14}$ He suggests that, through the use of different terminology, both the international community as a whole and individual nations will be able to trespond more nimbly to threats of impending genocide. One of the most effective ways to prevent or suppress a genocide, Scheffer seems to be saying, is to avoid actually using the term.

Scheffer's proposal of shunning the term "genocide" is limited to diplomatic contexts, or what he calls "the political application of the term"; ${ }^{15}$ he recognizes that genocide also has a "legal application" and a "historical application."16

In the legal arena, the term "genocide" requires an act of looking backward, used in prosecuting individuals-before either an international court or a domestic tribunal-to determine whether their prior conduct meets the mens rea and actus reus elements of the crime of genocide as set out in the UNCG. The historical use of the term demonstrates another instance of a process of looking backward, involving efforts by various aggrieved groups—such as the victims and heirs of the Armenian Genocide or of Stalin's Holodomor in the Ukraine in the 1930s-to have both the 
international community and individual nations agree that past crimes committed against them can also be stamped with the ultimate term of opprobrium.

In both of these instances, the use of Lemkin's word is perfectly proper. The crime of genocide is "on the books" of international law and must be called by its proper name. In keeping with the seriousness of the offense, the legal requirements of the crime are difficult to meet. In those situations where acts by perpetrators do amount to genocidal behavior, the term "genocide" must be used. Similarly, if a historical event, including one that occurred before the enactment of the UNCG, bears substantial similarity to events already recognized as a genocide-whether it be the Holocaust or the Rwandan genocide-the term "genocide" must be used to describe that event. It is a tribute to the enormous popularity of the term that, for the aggrieved victim group, no other term-whether it be "genocidal massacre," "a genocide-like event," "crime against humanity," "politicide" or "democide," or even Scheffer's "atrocity"-will do.

In the political arena, where we are not looking backward but attempting an accurate description of current events, the use of the term "genocide" now appears, as Scheffer points out, to have a hindering rather than a helpful effect. Again, this effect is due to the enormous emotional impact that the use of the term "genocide" produces. Because it clouds the issue rather than clarifying reality, and can indeed act as an obstacle to genocide prevention, then, on purely practical grounds, Scheffer's suggestion that the use of the G-word is best avoided is sound.

Scheffer's second proposal—that genocides, crimes against humanity, war crimes, and other crimes that can be prosecuted before international and hybrid tribunals be given the generic name "atrocity"-also has the advantage of using just one word to describe a host of crimes that have complex and hard-to-understand legal meanings and which at the same time also overlap with one another. Why try to find the precise legal term for the ongoing events, Scheffer argues, when the "unifying term" so "easily and accurately describe[s] the totality of these crimes?"17 Since the term "atrocity," as Scheffer points out, also has no legal meaning, it ironically has the advantage over the term "genocide," since its use by politicians and diplomats has no legal ramifications.

Scheffer, however, is not satisfied for the term "atrocity" to be used only by politicians, diplomats, the media, and the public. The final part of his proposal calls for the adoption of the term "atrocity law" into the legal lexicon. "Atrocity law" is meant to describe the body of international law dealing with the basket of crimes-genocide, crimes against humanity, war crimes, and other serious offenses-over which international and hybrid criminal tribunals now, or may in the future, have jurisdiction. ${ }^{18}$ Scheffer aims to assign to these crimes the generic legal name of "atrocity crimes."

A significant motivation for the adoption of these terms is that, as Scheffer concedes, they are easily understood by the general public. Their legal adoption will lead to their popular adoption, and thus should help to bring further prestige to international tribunals by providing an understandable term to describe to the public what exactly these tribunals do. "Atrocity law," as Scheffer aptly explains, is vastly preferable to terms currently bandied about by international human-rights activists and before international bodies to describe such crimes in general. ${ }^{19}$ Such termsincluding "international humanitarian law," "international human rights law," "international criminal law," "military law," and "laws of war"-are incomprehensible to the general public because they overlap, are not well defined, and are used sloppily not only by the media but also by legal professionals. 
Simplicity is always a worthy goal, and, especially in the opaque worlds of law and diplomacy, Scheffer's proposal has much merit. Given that it is meant to be used in the international arena, the term "atrocity" also has an advantage in possessing similar-sounding equivalents in other popular diplomatic languages: atrocité in French; atrocidad in Spanish; atrocità in Italian. ${ }^{20}$

It remains to be seen whether the term will catch on, either in the international diplomatic arena or with legal scholars, the media, and the general public. At the time of writing, a Google search of "atrocity crimes" yields about 9,210 appearances on the Internet; "atrocity law" merits only about 648 entries, many of them relating to Belgium's controversial universal jurisdiction statute, known in English as the Anti-Atrocity Law. A fair start for a Lemkin-like campaign that made its first appearance in print in 2002, with Scheffer's law-review article "The Future of Atrocity Law."21

\section{Notes}

1. Raphael Lemkin, Axis Rule in Occupied Europe: Laws of Occupation; Analysis of Government; Proposals for Redress (Washington, DC: Carnegie Endowment for International Peace, 1944), 79.

2. The principle of universal jurisdiction is set out in the Restatement (Third) of Foreign Relations Law (1987) § 702. See also Stephen Macedo, ed., Universal Jurisdiction: National Courts and the Prosecution of Serious Crimes under International Law (Philadelphia: University of Pennsylvania Press, 2006).

3. Convention on the Prevention and Punishment of the Crime of Genocide, 9 December 1948, 78 U.N.T.S. 277.

4. William Schabas, Genocide in International Law: The Crime of Crimes (Cambridge: Cambridge University Press, 2000), 9. The phrase "crime of crimes" comes from opinions issued in two genocide trials before the International Criminal Tribunal for Rwanda.

5. Gregory H. Stanton, "How We Can Prevent Genocide: Building an International Campaign to End Genocide" (Genocide Watch, 2003), http://www.genocidewatch.org/ HOWWECANPREVENTGENOCIDE.htm (accessed 3 January 2007).

6. Jerry Fowler, "A New Chapter of Irony: The Legal Implications of the Darfur Genocide Determination," Genocide Studies and Prevention 1 (2006): 29-39, 29.

7. See, e.g., Leo Kuper, The Prevention of Genocide (New Haven, CT: Yale University Press, 1985); John G. Heidenrich, How to Prevent Genocide: A Guide for Policymakers, Scholars, and the Concerned Citizen (Westport, CT: Praeger Publishers, 2001); Herbert Hirsch, Anti-Genocide: Building an American Movement to Prevent Genocide (New York: Praeger Publishers, 2002).

8. Israel W. Charny with Chanan Rapaport, "Toward a Genocide Early Warning System," in How Can We Commit the Unthinkable? Genocide, the Human Cancer, ed. Israel W. Charny, 283-331 (Boulder, CO: Westview Press, 1982). A good summary of GEWS can be found in Israel W. Charny, ed., The Encyclopedia of Genocide, vol. 1 (Santa Barbara, CA: Clio Press, 1999) 253-61.

9. Gregory H. Stanton, "The Eight Stages of Genocide" (Genocide Watch, 1998), http://www.genocidewatch.org/8stages2006.htm (accessed 3 January 2007). Stanton's eight stages are (1) classification; (2) symbolization; (3) dehumanization; (4) organization; (5) polarization; (6) preparation; (7) extermination; and (8) denial.

10. David Scheffer, "Genocide and Atrocity Crimes," Genocide Studies and Prevention 1 (2006): 229-50, 248.

11. Ibid.

12. Ibid., 232.

13. Ibid.

14. Ibid. 
15. Ibid., 230.

16. Ibid.

17. Ibid., 238.

18. Ibid., 244.

19. Ibid.

20. In German, "atrocity" is translated as Grausamkeit; in Dutch it is wreedheid, and in Russian it is зверство [zverstvo].

21. David J. Scheffer, "The Future of Atrocity Law," Suffolk Transnational Law Review 25 (2002): 389-432. 